\title{
Earthworm communities in alluvial forests: Influence of altitude, vegetation stages and soil parameters
}

\author{
Clémence Saloméa , Claire Guenat ${ }^{\mathrm{b}}$, Géraldine Bullinger-Weber ${ }^{\mathrm{c}}$, Jean-Michel Gobat ${ }^{\mathrm{a}}$, \\ Renée-Claire Le Bayon ${ }^{\mathrm{a}, *}$ \\ a Laboratory Soil and Vegetation, University of Neuchâtel, Emile-Argand Street 11, CH-2000 Neuchâtel, Switzerland \\ ${ }^{\mathrm{b}}$ Laboratory of Ecological Systems, École Polytechnique Fédérale de Lausanne (EPFL), Station 2, CH-1015 Lausanne, Switzerland \\ ${ }^{\mathrm{c}}$ Biogeosciences Laboratory, Institute of Geology \& Paleontology, University of Lausanne, CH-1015 Lausanne, Switzerland
}

\section{A R T I C L E I N F O}

\section{Article history:}

Received 17 November 2010

Received in revised form 15 July 2011

Accepted 24 September 2011

\section{Keywords:}

Earthworms

Floodplains

Alluvial forests

Fluvisols/FLuviosols

Altitude

\begin{abstract}
A B S T R A C T
In many terrestrial ecosystems, soil parameters usually regulate the distribution of earthworm communities. In alluvial ecosystems, few studies have investigated the impact of periodic floods and alluvium deposition on soil fauna. In this context, we assumed that earthworm communities may vary depending on altitude (alpine, subalpine, mountain and hill levels), forest successional stage (post-pioneer to mature forests) and some soil parameters. Our results demonstrated that the composition of earthworm communities differed depending on altitudinal gradients. No earthworm was found at the alpine level while maximum density and biomass were observed at the hill level mainly due to the contribution of anecic species. A total of 27 species and subspecies were found over the three sampling sites, and Lumbricus moliboeus was discovered for the first time in carbonated soils. Soil texture had a major effect on epigeics that were often associated with coarse sandy texture in contrast to anecics which preferred deep soils and mature forest stages, which in combination provided the highest carbon content and the finest soil texture. In our study, carbonated fluviosols (Fluvisols according to the World Reference Base) were recorded; FLUVIOSOLS TYPIQUES with well-structured A layers were generally found in mature or intermediate forest stages while most of FLuviosols JUVENILES with heterogeneous texture were observed principally in post-pioneer forests. We conclude that in alluvial ecosystems, earthworm communities were highly dependent first on soil parameters, then altitude and to a lesser extent forest successional stages. Changes in earthworm communities tend to reflect a gradient of alluvial dynamics thus reinforcing the potential role of earthworms as bioindicators in natural and/or semi natural alluvial ecosystems.
\end{abstract}

(c) 2011 Elsevier GmbH. All rights reserved.

\section{Introduction}

Earthworms modify their environment by changing the distribution of materials and energy transfer in soil food webs that consequently induce the creation and/or destruction of habitats dedicated to subordinate species (Jones et al. 1997; Wright et al. 2004). In many terrestrial ecosystems, earthworms are considered as major ecosystem engineers (Edwards and Bohlen 1996; Lavelle et al. 1997). Through bioturbation, such as burrowing, casting and mixing of organic material and mineral particles, earthworms influence both soil physical (soil structure, water infiltration) and biological properties (organic matter decay, microbial activities) (Lee 1985; Edwards and Bohlen 1996). In turn, soil parameters have some influence on the distribution of earthworm communities. It

\footnotetext{
* Corresponding author. Tel.: +41 327182365.

E-mail address: claire.lebayon@unine.ch (R.-C. Le Bayon).
}

is indeed soil texture combined with vegetation types, food supply and $\mathrm{pH}$ values that largely determine earthworm densities in natural (i.e. uncontaminated) environments (Lavelle 1988; Ammer et al. 2006; Lapied et al. 2009).

In floodplain environments, soils exhibit more complex characteristics. They are regularly flooded by surface- or ground-waters, which sometimes leads to occasional or temporary waterlogging of soils. Also, depending on the position of soil in the landscape, discharge fluctuations, frequency and intensity of flooding events as well as organic matter supply, can cause variation in soil physicochemical composition, leading to a wide diversity of soil layers and soil types. FLUVIosols (Baize and Girard 2009) or Fluvisols (IUSS Working Group WRB 2006) represent some of the soils that are usually found in these ecosystems.

So far, few studies have investigated the impact of periodic floods and the variations of alluvium depositions on earthworm communities. Mather and Christensen (1988) assumed that, in flooded soils, earthworms' main physical stress could be due to 
the degree to which soil conditions are anaerobic. Some authors concluded that both earthworm biomass and earthworm diversity are significantly lower in flooded soils than in non-flooded ones (Pizl 1999; Ausden et al. 2001; Plum 2005; Ivask et al. 2007). However, Schütz et al. (2008) found higher numbers and biomass in flooded soils in systems used for drinking water production. Zorn et al. (2005) showed that earthworm populations fluctuate temporally, depending on flooding dynamics; moreover, they highlighted the species-specific response of earthworm population. In these systems, cocoons that are able to survive flooding events as well as active dispersion of earthworms are essential to ensure communities' survival.

In previous citations (Ausden et al. 2001; Zorn et al. 2005; Ivask et al. 2007), studies mainly focused on flooded grasslands situated below $200 \mathrm{~m}$ above sea level. In the past, rivers were embanked for land-use purposes and floodplains are thus usually characterised by permanent pastures or agricultural fields. By contrast, natural floodplains usually abound in forests revealing a gradient of vegetation from softwood to hardwood that provide a heterogeneous landscape as well as a large diversity of biological habitats (Petts and Amoros 1996; Ward et al. 2002). Research in these floodplain ecosystems has mainly focused on riparian vegetation biodiversity, succession and productivity (Schnitzler-Lenoble 2007) but also on amphibians' biodiversity (Tockner et al. 2006), birds (McGinness et al. 2010) and mammals (Williams et al. 2001). Invertebrates and benthic fauna were also described (Korte et al. 2010).
Switzerland's land-planning regulation has accounted for the ecological value of such floodplains for a number of years and has therefore inventoried those 227 alluvial zones and pro-glacial areas of national importance (Kuhn and Amiet 1988). These zones were mapped using vegetation types as units (Gallandat et al. 1993). However, relatively few studies have been conducted on terrestrial invertebrates such as earthworms (Guenat et al. 1999; BullingerWeber et al. 2007).

The mosaic of soil texture and vegetation, as well as the fluctuations of the fluvial dynamics, causes wide ecosystem heterogeneity where earthworm communities are expected to vary. In this context, the present study focused on natural alluvial ecosystems with respect to three potential influences: (i) altitude, (ii) forest successional stage and (iii) soil characteristics, assuming that earthworm communities (ecological groups, species, abundance, and biomass) and their spatial distribution may vary depending on altitudinal level (alpine, subalpine, mountain and hill levels), forest stages (post-pioneer to mature forests) and some soil parameters.

\section{Materials and methods}

\section{Site descriptions}

For this study, four floodplains were chosen. The sites were located at four different altitudes (alpine, subalpine, mountain and hill levels) and all of them originated from calcareous alluvial

Table 1

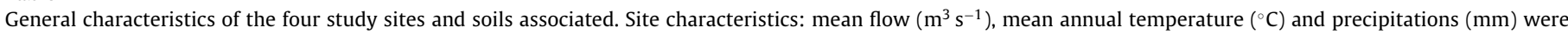
calculated over a period of minimum 30 years.

\begin{tabular}{|c|c|c|c|c|c|}
\hline & $\begin{array}{l}\text { Level (altitude: m } \\
\text { above sea level) }\end{array}$ & Alpine (2300 m) & Subalpine (1370 m) & Mountain (750 m) & Hill (350 m) \\
\hline \multirow[t]{8}{*}{ Site characteristics } & Location & $46^{\circ} 23^{\prime} 43 \mathrm{~N}, 7^{\circ} 35^{\prime} 21 \mathrm{E}$ & $46^{\circ} 28^{\prime} 01 \mathrm{~N}, 7^{\circ} 39^{\prime} 47 \mathrm{E}$ & $46^{\circ} 32^{\prime} \mathrm{N}, 7^{\circ} 04^{\prime} \mathrm{E}$ & $47^{\circ} 28^{\prime} \mathrm{N}, 8^{\circ} 10^{\prime} \mathrm{E}$ \\
\hline & $\begin{array}{l}\text { Channel pattern type } \\
\text { (Rust } 1978 \text { in Petts and } \\
\text { Amoros 1996) }\end{array}$ & Pro-glacial margin & Braided river & Braided river & Meandering river \\
\hline & Mean flow $\left(\mathrm{m}^{3} \mathrm{~s}^{-1}\right)$ & Data not available & Mean: 2.1 & Mean: 23.3 & Mean: 316 \\
\hline & Mean annual temperature & $T=0^{\circ} \mathrm{C}$ & $T=5.4^{\circ} \mathrm{C}$ & $T=6.5^{\circ} \mathrm{C}$ & $T=8.8^{\circ} \mathrm{C}$ \\
\hline & $\left({ }^{\circ} \mathrm{C}\right)$ and precipitations $(\mathrm{mm})$ & $P=1188 \mathrm{~mm}$ & $P=1180 \mathrm{~mm}$ & $P=1250 \mathrm{~mm}$ & $P=1060 \mathrm{~mm}$ \\
\hline & $\begin{array}{l}\text { Forest stages (Forests } \\
\text { according to Gallandat } \\
\text { et al. 1993) }\end{array}$ & $\begin{array}{l}\text { Pioneer vegetation: } \\
\text { (Epilobium fleischeri, } \\
\text { Saxifraga sp.) }\end{array}$ & $\begin{array}{l}\text { Post-pioneer: bushes of } \\
\text { Salix eleagnos }\end{array}$ & $\begin{array}{l}\text { Post-pioneer: forests of } \\
\text { Salix eleagnos }\end{array}$ & $\begin{array}{l}\text { Post-pioneer: forests of } \\
\text { Salix alba }\end{array}$ \\
\hline & & & $\begin{array}{l}\text { Intermediate: forests of } \\
\text { Alnus incana }\end{array}$ & $\begin{array}{l}\text { Intermediate: forests of } \\
\text { Alnus incana }\end{array}$ & $\begin{array}{l}\text { Intermediate: forests of } \\
\text { Alnus incana }\end{array}$ \\
\hline & & & $\begin{array}{l}\text { Mature: old forests of } \\
\text { Alnus incana }\end{array}$ & $\begin{array}{l}\text { Mature: alder and ash } \\
\text { (Fraxinus excelsior) } \\
\text { riparian transition } \\
\text { forests }\end{array}$ & $\begin{array}{l}\text { Mature: alder and ash } \\
\text { (Fraxinus excelsior) } \\
\text { riparian transition } \\
\text { forests }\end{array}$ \\
\hline \multirow[t]{15}{*}{$\begin{array}{l}\text { General soil } \\
\text { parameters }\end{array}$} & Total soil depth $(\mathrm{cm})$ & $10 \pm 12(0-24)$ & $30.7 \pm 20.3(3-57)$ & $43.0 \pm 16.8(24-73)$ & $\begin{array}{l}113.8 \pm 10.8 \text { (90 to } \\
\geq 120)\end{array}$ \\
\hline & $\begin{array}{l}\text { Depth of first } \\
\text { appearance of } \\
\text { hydromorphic features } \\
(\mathrm{cm})\end{array}$ & $\begin{array}{l}\text { No hydromorphic } \\
\text { features }\end{array}$ & $11.3 \pm 9.7(1-44)$ & $\begin{array}{l}\text { No hydromorphic } \\
\text { features }\end{array}$ & $67.7 \pm 25.5(8-90)$ \\
\hline & Alluvial dynamic index & $6 \pm 7(1-15)$ & $3.6 \pm 1.6(1-7)$ & $3.3 \pm 1.1(2-5)$ & $2.3 \pm 0.7(1-4)$ \\
\hline & $\begin{array}{l}\mathrm{C}_{\text {org }} \text { stock }\left(\mathrm{kg} \mathrm{m}^{-2} \text { to }\right. \\
30 \mathrm{~cm} \text { depth })\end{array}$ & $0.04 \pm 0.04$ & $3.7 \pm 2.9(0.1-9.9)$ & $5.6 \pm 2.0(2.1-8.6)$ & $5.2 \pm 1.7(2.1-7.2)$ \\
\hline & $\mathrm{C} / \mathrm{N}$ ratio & $9.7 \pm 3.4(6.4-14.7)$ & $16.7 \pm 4.3(13.5-22.9)$ & $13.9 \pm 1.4(12.3-16.9)$ & $12.8 \pm 1.6(11.1-17.6)$ \\
\hline & Total $\mathrm{CaCO}_{3}\left(\mathrm{~g} \mathrm{~kg}^{-1}\right)$ & $553 \pm 34(510-604)$ & $448 \pm 78(250-608)$ & $535 \pm 129(343-722)$ & $206 \pm 12(174-230)$ \\
\hline & Soil types by forest & FLUVIOSOLS BRUTS & Post-pioneer stage: & Post-pioneer stage: & Post-pioneer stage: \\
\hline & stages (according to & & FLUVIOSOLS JUVENILES & FLUVIOSOLS JUVENILES & FLUVIOSOLS JUVENILES, \\
\hline & Baize and Girard 2009) & & REDOXISOL fluvique & & FLUVIOSOLS TYPIQUES \\
\hline & & & Intermediate stage: & Intermediate stage: & Intermediate stage: \\
\hline & & & FLUVIOSOLS BRUTS & FLUVIOSOLS TYPIQUES & FLUVIOSOLS JUVENILES \\
\hline & & & FLUVIOSOLS JUVENILES & & FLUVIOSOLS TYPIQUES \\
\hline & & & Mature stage: & Mature stage: & Mature stage: \\
\hline & & & FLUVIOSOLS JUVENILES & FLUVIOSOLS TYPIQUES & FLUVIOSOLS JUVENILES \\
\hline & & & FLUVIOSOLS TYPIQUES & & FLUVIOSOLS TYPIQUES \\
\hline
\end{tabular}

Source: http://www.bafu.admin.ch/schutzgebiete-inventare/07839/index.html?lang=de.

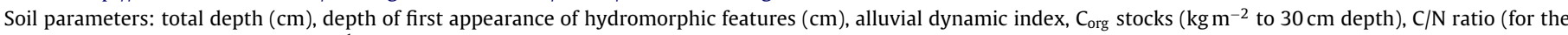

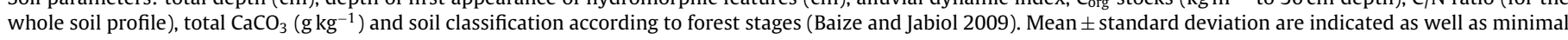
and maximal values into brackets. 
deposits. They have been subject to minimal human impact and exhibit natural hydrological dynamics where deposition and erosion processes still occur. General characteristics of these sites are given in Table 1.

\section{Experimental design}

Based on vegetation maps, and except for the alpine areas where only pioneer vegetation was observed, three forests stages were distinguished inside each site: post-pioneer, intermediate and mature (see Table 1 for more details on these forests; Gallandat et al. 1993). The number of samples selected for each site depended on the presence of these vegetation stages, therefore, leading to an unbalanced design. Thus, three plots were sampled at the alpine level. At the subalpine level, three, six and six plots were sampled in post-pioneer, intermediate and mature stages, respectively. At the mountain level, five plots were sampled in post-pioneer, three in intermediate and four in mature stages. Finally, at the hill level, six plots were sampled in each forest stage. In every case, sampling plots were separated by at least $20 \mathrm{~m}$ to avoid any neighbour effect. A total of 48 plots $(3,15,12$ and 18 at alpine, subalpine, mountain and hill levels, respectively) were sampled.

\section{Soil sampling and physicochemical analyses}

For each of the 48 plots, a soil profile and the corresponding humus form were described (total depth, number of successive alluvium deposits in the first $30 \mathrm{~cm}$, appearance of hydromorphic features) and classified according to the International Soil Taxonomy of the IUSS Working Group WRB (2006). Moreover, the Baize and Girard (2009) classification was used for a more detailed and genetic approach to the alluvial soils (four references instead of one). Soil layers from the first $30 \mathrm{~cm}$ were collected and analysed in the laboratory. Organic carbon ( $\left.\mathrm{C}_{\text {org }}\right)$, total nitrogen $\left(\mathrm{N}_{\text {tot }}\right)$, total $\mathrm{CaCO}_{3}$, and particle size distribution (modified Robinson pipette method) were determined according to Carter and Gregorich (2007). For this latter parameter, different textural layers were observed within the first $30 \mathrm{~cm}$ for most of the soils, thus choosing one reference layer that would characterise topsoil was not possible. As a consequence, particle size distribution was referred to a granulometric class according to the textural triangle (U.S.D.A.) for each soil layer. The different textural classes represented, therefore, the textural variables for which relative thickness of layers by profile was attributed. To calculate stocks of $C_{\text {org }}$, bulk density of soil layers ( 3 replicates) was estimated by weighing dry soil, sieved at $5 \mathrm{~mm}$, in a standard volume.

\section{Earthworm sampling}

Earthworms were collected using the standard mustard extraction (Lawrence and Bowers 2002) in three replicates of $1 \mathrm{~m}^{2}$ plots near each soil profile. Earthworms were immediately stored in formaldehyde $4 \%(v / v)$. The "hand sorting" method was also done as a complement to ensure that no earthworm remained in the soil after chemical extraction. In the middle of the square meter plots sampled, a cube $(20 \mathrm{~cm} \times 20 \mathrm{~cm} \times 20 \mathrm{~cm})$ was extracted and carefully hand sorted: all earthworms were collected and also stored in formaldehyde $4 \%(\mathrm{v} / \mathrm{v})$. Data were then combined with those of the mustard extraction using a multiplying factor of 25 . This sampling was performed twice a year at the end of spring and autumn 2008 in order to obtain an accurate estimate of the entire earthworm community. These data were then pooled for statistical analyses. Earthworms were identified at least to the species level (Bouché 1972; Sims and Gerard 1999) and named according to Blakemore's list (2007) before being classified according to ecological categories (Bouché 1977). Each adult and sub-adult were counted and weighed. Unidentified juveniles were attached to species level using a pro rata distribution according to adult and sub-adult proportions.

\section{Statistical analyses}

The effect of altitude on earthworm abundance, biomass and ecological categories was tested using a nested ANOVA for which altitude was the principal factor and forest stage the subordinate one. The absence of earthworms at the alpine level permitted this statistical analysis. The effect of forest stage within each site was tested with one way ANOVAs. Tukey's HSD post hoc tests were performed when ANOVAs were significant. When necessary, data were square root transformed to respect the conditions for normality and the homogeneity of variance. To study the relative importance of the three factors (altitude, forest stage and soil parameters) influencing earthworm communities, we first performed a variation partitioning analysis using a series of partial RDAs (Redundancy Analysis) to display the variability explained by each data set. For this analysis, three sets of explanatory variables were employed: a soil matrix including physicochemical analyses, altitude and forest stage coded as dummy variables. The Monte Carlo permutation test was subsequently performed to test significance of these partial RDAs. Then, a RDA was used for all the variables. The soil matrix was composed of soil depth, the depth where the first hydromorphic features appeared, the thickness of holorganic layers accumulated at the soil surface, $C_{\text {org }}$ stocks, textural classes with the relative thickness of each layer and an alluvial dynamic index (number of successive alluvium deposits in the first $30 \mathrm{~cm}$ ). The species abundance matrix was Hellinger-transformed (Legendre and Gallagher 2001), subspecies were gathered at the species level and species appearing in very few plots (called for the study "infrequent species") were removed from the analysis.

All statistical treatments were performed with $\mathrm{R}$ software ( $\mathrm{R}$ Development Coreteam 2008) using vegan package for multivariate analysis.

\section{Results}

Soils

All the soils, except one, were described as Fluvisols according to the IUSS Working Group WRB (2006). Using the Baize and Girard classification (2009), soils belong to three references that correspond to three different stages of alluvial soil evolution (FLUVIOSOLS BRUTS, FLUVIOSOLS JUVENILES, FLUVIOSOLS TYPIQUES). Hydromorphic features were infrequent and generally confined within deep layers, except for one soil (Stagnosol), at subalpine level, where hydromorphic spots appeared within the first several centimetres. The Stagnosol name corresponds to REDOXIsol fluvique using the Baize and Girard classification (2009). FLUVIOSOLS BRUTS were the unique reference at the alpine level and were only found in the intermediate forest stage of the subalpine level, while FLuviosols JUVENILES and FLUVIOSOLS TYPIQUES were present from subalpine to hill levels. Regarding humus forms, Mulls characterised all soil profiles at both hill and mountain levels, whereas at the subalpine level, fLuviosols JUVENILES generally presented Mulls and FLuVIOSOLS TYPIQUES or FLUVIOSOLS BRUTS had characteristics closer to Moders. Generally, within each altitudinal level, soils had very heterogeneous physico-chemical characteristics.

Following the altitudinal gradient (from alpine to hill levels), soil depth increased to more than $120 \mathrm{~cm}$ (Table 2). The highest alluvial dynamic index was found at the alpine level, and there was a statistically insignificant decrease in this index with increasing altitude. Considering soil organic matter, the highest $\mathrm{C}_{\text {org }}$ stock 


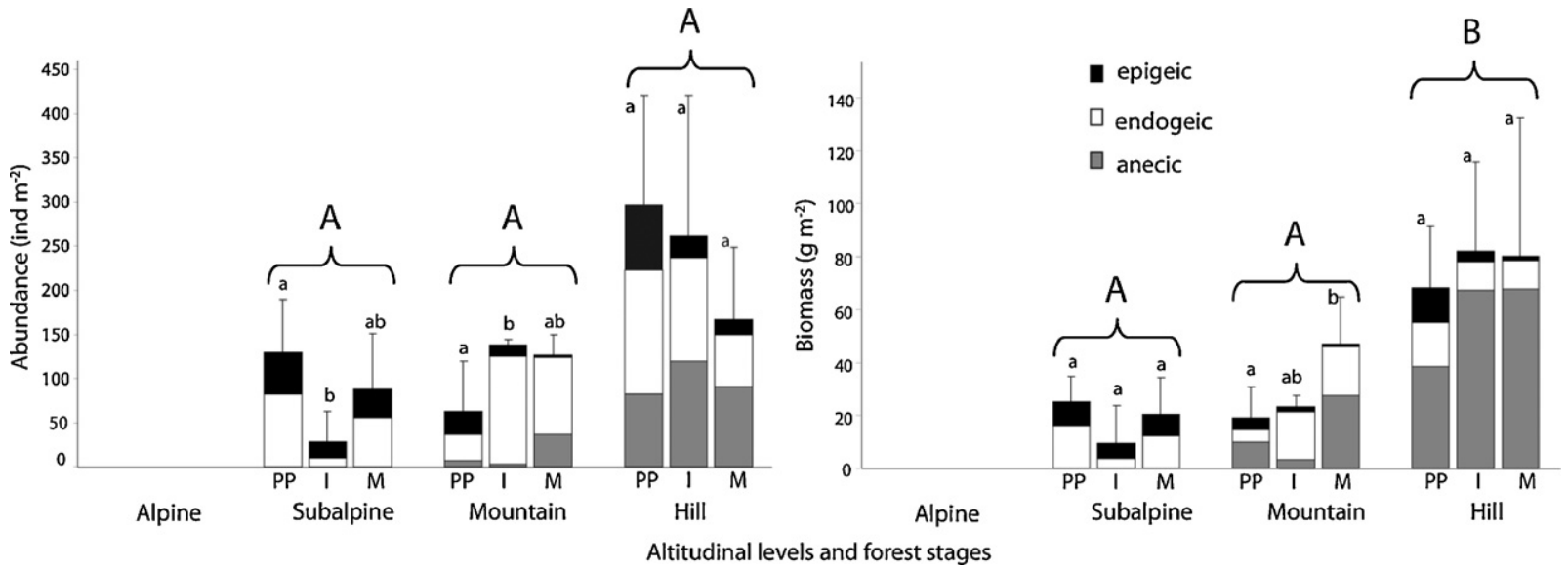

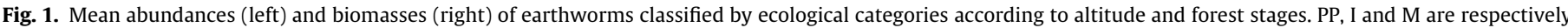

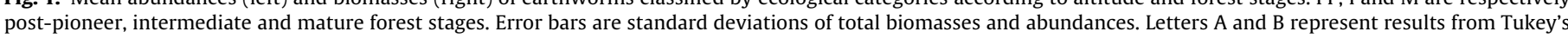

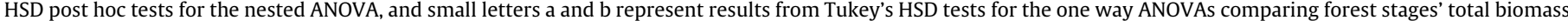
and abundance at each altitudinal level (see Table 3 for the $F$-values).

variations were observed at the subalpine level. These stocks were generally very low compared to the other sites, while $\mathrm{C} / \mathrm{N}$ ratios, at the alpine level, were lower than those observed at other altitudes. These ratios slightly decreased from subalpine to hill levels and the highest variations were observed at the subalpine level. At each altitudinal level (except alpine), layer texture belonged to five granulometric classes: silty loam, loamy, sandy loam, loamy sand, and sandy (Fig. 1). Mature forest soils were mainly characterised by the finest texture whereas soils from post-pioneer and intermediate forests showed a more heterogeneous texture (Fig. 1). Total $\mathrm{CaCO}_{3}$ content was clearly associated with basic soil environments, and $\mathrm{pH}$ (in water) measurements done on organo-mineral layers showed values ranging from 7.43 to 8.28 (data not shown).

\section{Earthworm communities}

A total of 27 species and subspecies were found in this study (11, 20 and 19 at the subalpine, mountain and hill levels, respectively) and no earthworm was recorded at the alpine level (Table 2). Approximately $50 \%$ of the earthworms were considered as infrequent species because they were either represented by isolated individuals or observed only in few soil profiles. These infrequent species, belonging to all ecological categories, were collected at hill and mountain levels. Aporrectodea caliginosa caliginosa, Aporrectodea rosea, Dendrobaena octaedra, Dendrodrilus rubidus, Lumbricus rubellus and Octolasion tyrtaeum were widely recorded in the three sites. However, the subspecies 0 . t. tyrtaeum was especially present

Table 2

List of taxa and frequencies of their presence in the different sampling plots.

\begin{tabular}{|c|c|c|c|c|}
\hline & \multicolumn{4}{|c|}{ Number of sampling plots where species were collected } \\
\hline & Alpine $N=3$ & Subalpine $N=15$ & Mountain $N=12$ & Hill $N=18$ \\
\hline \multicolumn{5}{|l|}{ Epigeic species } \\
\hline Dendrobaena octaedra (Savigny, 1826) & - & 15 & 9 & 13 \\
\hline Dendrodrilus rubidus rubidus (Savigny, 1826) & - & 3 & 1 & 7 \\
\hline Dendrodrilus subrubicundus (Eisen, 1874) & - & 7 & 2 & 4 \\
\hline Lumbricus meliboeus (Rosa, 1884) & - & 10 & - & - \\
\hline Lumbricus rubellus (Hoffmeister, 1843) & - & 13 & 10 & 14 \\
\hline Eisenia andrei ${ }^{\mathrm{a}}$ (Bouché, 1972) & - & - & - & 1 \\
\hline Octodrilus argoviensis ${ }^{\mathrm{a}}$ (Bretscher, 1899) & - & - & - & 1 \\
\hline Lumbricus castaneus $^{\mathrm{a}}$ (Savigny, 1826) & - & - & - & 1 \\
\hline Eiseniella tetraedra tetraedra ${ }^{\mathrm{a}}$ (Savigny, 1826) & - & - & 1 & 2 \\
\hline Dendrobaena pygmea pygmea ${ }^{\mathrm{a}}$ (Savigny, 1826) & - & - & 1 & - \\
\hline Dendrobaena pygmea cognetti ${ }^{\mathrm{a}}$ (Michaelsen, 1903) & - & - & 1 & - \\
\hline Bimastos eiseni ${ }^{\mathrm{a}}$ (Levinsen, 1884) & - & - & 1 & - \\
\hline \multicolumn{5}{|l|}{ Anecic species } \\
\hline Aporrectodea caliginosa nocturna (Evans, 1946) & - & - & 6 & 18 \\
\hline Lumbricus terrestris (Linnaeus, 1758) & - & - & 11 & 13 \\
\hline Aporrectodea longa ripicola ${ }^{\mathrm{a}}$ (Bouché, 1972) & - & - & 3 & - \\
\hline Aporrectodea l. ripicola viridis ${ }^{\mathrm{a}}$ (Bouché, 1972) & - & - & 2 & - \\
\hline Aporrectodea longa longa ${ }^{\mathrm{a}}$ (Ude, 1885) & - & - & - & 1 \\
\hline Aporrectodea giardi giardi ${ }^{\mathrm{a}}$ (Ribaucourt, 1901) & - & - & - & 2 \\
\hline \multicolumn{5}{|l|}{ Endogeic species } \\
\hline Allolobophora chlorotica chlorotica (Savigny, 1826) & - & - & 4 & 2 \\
\hline Aporrectodea caliginosa caliginosa (Savigny, 1826) & - & 5 & 9 & 17 \\
\hline Aporrectodea handlirschi handlirschi (Rosa, 1905) & - & 9 & - & 1 \\
\hline Aporrectodea icterica icterica (Savigny, 1826) & - & - & 3 & 6 \\
\hline Aporrectodea rosea rosea (Savigny, 1826) & - & 7 & 9 & 12 \\
\hline Octolasion cyaneum (Savigny, 1826) & - & 4 & 1 & - \\
\hline Octolasion tyrtaeum lacteum (Oerley, 1885) & - & 11 & 12 & 11 \\
\hline Octolasion tyrtaeum tyrtaeum (Savigny, 1826) & - & 11 & 1 & 4 \\
\hline Aporrectodea caliginosa alternitosa ${ }^{\mathrm{a}}$ (Bouché, 1972) & - & - & 3 & - \\
\hline
\end{tabular}

\footnotetext{
a Species considered as infrequent species in this study.
} 
at the subalpine level whereas subspecies 0 . t. lacteum was found in all sites. Lumbricus moliboeus was the only abundant species present exclusively at the subalpine level. Aporrectodea caliginosa nocturna dominated the anecics at the hill level. Finally, no anecic was found at the subalpine level.

Maximum earthworm biomass was found at the hill level in a plot from mature forest for biomass $\left(159 \mathrm{~g} \mathrm{~m}^{-2}\right)$ while maximum abundance was observed in intermediate forest at the same forest stage $\left(523\right.$ ind $\left.\mathrm{m}^{-2}\right)$. The lowest biomass $\left(0.1 \mathrm{~g} \mathrm{~m}^{-2}\right)$ and abundance ( 1.3 ind $\mathrm{m}^{-2}$ ) were measured at the subalpine level in a soil under an intermediate successional stage. Significant differences between altitudinal levels were found (Table 3 and Fig. 2) particularly at the hill level, which presented higher total biomass and abundance as well as higher biomass and abundance of anecics compared to mountain and subalpine levels. No clear trend was observable in comparing forest stages within each site (Fig. 2 and Table 3). At the hill level, total biomass and abundance of earthworms revealed no significant differences between the different forests; however, mean biomass and abundance of epigeics were higher in post-pioneer forests than in mature ones. At the mountain level, total biomass and abundance in mature forests, as well as abundance of earthworms in intermediate forests, were higher than in post-pioneer ones. Anecic abundances were also significantly higher in the mature forest. Endogeic abundance and biomass were significantly lower in the post-pioneer stage but epigeic species were more numerous in this latter stage compared to the mature one. Finally, at the subalpine level, earthworm abundance in post-pioneer stage was significantly higher than in intermediate one. Endogeic species were more numerous and their biomass was higher in the post-pioneer and mature stages than in the intermediate ones. Earthworm communities found under the same vegetation stages are very heterogeneous in terms of species abundance and biomass as revealed by the high standard deviations in Table 4.

\section{Effects of altitude, forest stages on earthworm species}

Variation partitioning analysis revealed that $49 \%$ of the species abundance matrix was significantly explained by studied variables (data not shown; Monte Carlo tests $P<0.01$ ). The descriptors displaying the highest part of explained variability were those of the soil matrix. Globally, $47 \%$ of the species variation was attributed to the soil data set. Altitude and forest stages explained $24.5 \%$ and $8.8 \%$ of the variability, respectively. However, $22.5 \%$ of the variation explained by altitude was shared with soil data set due to the correlation between these two factors. In the same way, the $8.8 \%$ of variation explained by forest stage was shared with soil data set.

The RDA (Fig. 3) explained $64 \%$ of the species abundance matrix. Global analysis and the three first axes (accounting respectively for $32.5 \%, 11.8 \%$ and $9.1 \%$ ) were significant. All variables were significant, except two textural ones (loamy sand and sandy loam) and the intermediate forest stage.

Two groups have been drawn along the first axis in Fig. 3a. On the left side of the graph, the first group was composed of deep soils with high $\mathrm{C}_{\text {org }}$ stocks and fine texture (mainly deep FLuviosols TYPIQUES). A. nocturna and $L$. terrestris were highly correlated with soil depth whereas $A$. rosea and $A$. icterica with $C_{\text {org }}$ and texture. On the right side of the first axis, soil parameters such as alluvial dynamic index, thickness of holorganic layers and coarse texture explained the presence of species such as O. tyrtaeum, L. rubellus L. meliboeus and $D$. octaedra. Finally, this first axis revealed soil parameters that reflect an altitudinal gradient. Three groups have been identified in Fig. 3b. The first one was characterised by soils with fine texture and high $C_{\text {org }}$ stocks at the subalpine and mountain levels, and by species such as $A$. rosea, $A$. handlirshi, O. cyaneum and A. icterica. These soils (mainly FLUVIOSOLS TYPIQUES) were found in mature
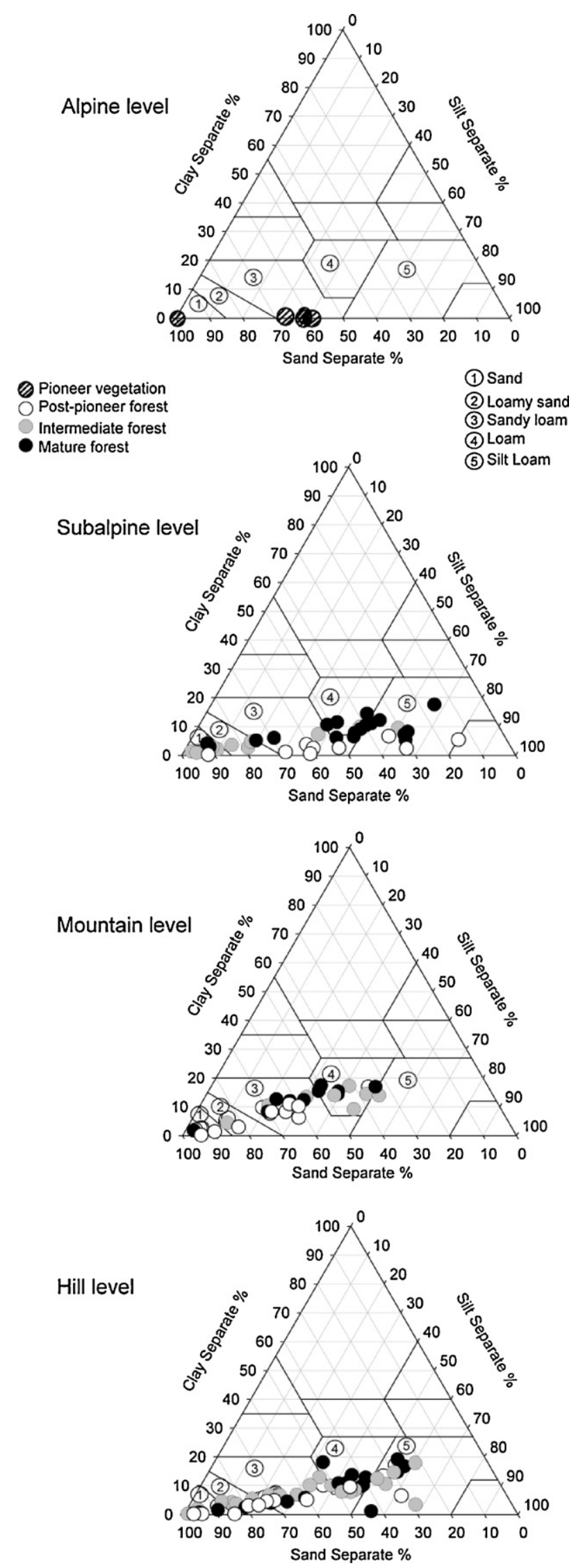

Fig. 2. Projection of soil layers into the soil texture triangle (USDA) according to altitudinal levels and forest stages. Texture classes found in our soils are described in the figure. 
Table 3

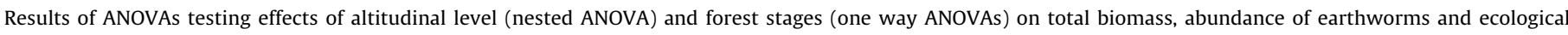
categories.

\begin{tabular}{|c|c|c|c|c|c|c|c|c|}
\hline \multirow[t]{3}{*}{ Factor tested } & \multicolumn{2}{|c|}{ All sites } & \multicolumn{2}{|c|}{ Subalpine } & \multicolumn{2}{|c|}{ Mountain } & \multicolumn{2}{|c|}{ Hill } \\
\hline & \multicolumn{2}{|c|}{ Altitude } & \multicolumn{2}{|c|}{ Forest stages } & \multicolumn{2}{|c|}{ Forest stages } & \multicolumn{2}{|c|}{ Forest stages } \\
\hline & $F_{2,6}$ & $P$ & $F_{2,12}$ & $P$ & $F_{2,9}$ & $P$ & $F_{2,15}$ & $P$ \\
\hline Total biomass & 12.7 & $<0.01$ & ns & ns & 5.6 & $<0.05$ & ns & ns \\
\hline Total abundance & 4.6 & 0.06 & 4.1 & $<0.05$ & 5.3 & $<0.05$ & ns & ns \\
\hline Epigeic biomass & ns & ns & ns & ns & ns & ns & 4.4 & $<0.05$ \\
\hline Epigeic abundance & ns & ns & ns & ns & 3.5 & $<0.1$ & 5.0 & $<0.05$ \\
\hline Endogeic biomass & ns & ns & 4.7 & $<0.05$ & 8.7 & $<0.01$ & ns & ns \\
\hline Endogeic abundance & ns & ns & 9.9 & $<0.01$ & 22.6 & $<0.01$ & ns & ns \\
\hline Anecic biomass & 18.9 & $<0.01$ & - & - & 3.4 & $<0.1$ & ns & ns \\
\hline Anecic abundance & 34.9 & $<0.01$ & - & - & 6.6 & $<0.05$ & ns & ns \\
\hline
\end{tabular}

$F_{\mathrm{a}, \mathrm{b}}$ are $F$-values of ANOVAs, with numerator and denominator degrees of freedom.

forests and some of them showed an accumulation of holorganic layers at the subalpine level. Another group was characterised by soils with coarse texture in the entire soil profile (mainly fLuviosols BRUTS) with species such as D. octaedra, and with $D$. rubidus to a lesser extent. Finally, the last group was composed by soils with heterogeneous texture, high alluvial dynamic index and some hydromorphic features reflecting high alluvial dynamics (mainly FLUVIOSOLS JUVENILES) where species such as A. chlorotica, A. cali. caliginosa, L. terrestris, $O$. tyrtaeum and $L$. rubellus were dominant.

\section{Discussion}

\section{Earthworm communities}

Biomass and abundance of earthworms have been shown to be very heterogeneous within and between sites. In this study, maximum biomass and density were found at the hill level. Our results are similar to those of Schütz et al. (2008) for the same altitude and are lower than those reported by Zorn et al. (2005) in floodplain soils along the Rhine River in the Netherlands (1912 ind $\mathrm{m}^{-2}$ and $276 \mathrm{~g} \mathrm{~m}^{-2}$, respectively). At the mountain level, maximum biomass and abundance were slightly lower than those observed by Bullinger-Weber et al. (2007). At the subalpine and alpine levels, the lack of research in similar ecosystems does not permit any comparison with our data set. The variability of earthworm communities can be favoured by a complex mosaic of habitats (Guenat et al. 1999).

In terms of diversity, a total of 27 species and subspecies were found, which represents two-thirds of all inventoried species in Switzerland. This confirms that floodplains are among the most diverse terrestrial ecosystems. Our infrequent species are either considered as rarities (A. cali. alternitosa, E. andrei, D. pygmea and $B$. eiseni) or confined to specific regions in Switzerland (A. giardi) and/or generally absent in forests (A. longa) (Bouché 1972; Cuendet 1997). Their presence could be due to passive dispersion from lateral slopes (Eijsackers 2010). Regarding other species, these are considered by Bouché (1972) as typically riparian (E. tetraedra and A. longa ripicola including green pigmented morph). Furthermore, L. moliboeus was recorded by Bouché (1972) as exclusively inhabiting acid soils in mountain environments. The discovery of this species in carbonated soils is new and would require further investigations.

Since FLuviosols are very young soils originating from recent fluvial deposits (IUSS Working Group WRB 2006; Baize and Girard 2009), all recorded earthworm species may be defined as pioneers for their ability to colonise new environments or as species able to resist to perturbations. Eijsackers (2010) highlighted that succession guilds in soil fauna could not be clearly defined, neither by $\mathrm{r}-\mathrm{K}$ strategy nor by morpho-ecological categories. For some pedological characteristics soil ecological amplitudes have to be taken into account

\section{Effects of altitudinal gradient and vegetation stages}

The presence of earthworm species differed along the altitudinal gradient. At the alpine level, no earthworm was recorded and at the subalpine level, neither infrequent species nor anecic species was sampled. These results are in agreement with macroecological studies that show that biodiversity of earthworms usually decreases when altitude increases from 1250 to $2250 \mathrm{~m}$ (Decaëns 2010). However, the lack of earthworm at alpine level does not mean that earthworms were not present at this altitude. Bouché (1972) and Cuendet (1986) found similar species (O. tyrtaeum, D. octaedra, D. rubidus, Lumbricus sp.) in pastures located at higher altitudes than our alpine site. The proximity of the glacier in La Gemmi may have led to unfavourable microclimatic conditions for earthworm colonisation (very low temperatures, no vegetation cover leading to low supply of organic matter and root networks). We observed that the absence of anecic earthworms at subalpine level was not due to altitude but rather to specific pedological conditions. When prospecting for an exhaustive overview of the potential distribution of earthworms at this altitude, we found $A$. cali. nocturna in an adjacent pasture to our floodplain site.

We also showed that earthworm biomass was predominantly higher at the hill level, because the anecic species with a large body size were abundant. By contrast, endogeics and epigeics showed no difference among altitude according to their biomass or abundance between altitudinal levels. The lack of anecic species at the subalpine level led to an accumulation of organic matter over the soil surface in the most developed forest stages thus maintaining favourable habitats for epigeics. Moreover, competition may influence the presence of given ecological categories. As discussed above, the predominance of anecics in mature forests at the mountain level, where they behave as competitors for food resources (Edwards 2004), may restrict the establishment of epigeic earthworms

Some trends in earthworm distribution were highlighted along both altitudinal and forest stage gradients. However, when considering pedological parameters, our results demonstrated that altitude and/or forest stages have an indirect impact that is by changing some pedological conditions such as soil depth, accumulation of organic matter and texture. These parameters are considered as the most important ones that control earthworm distribution. As suggested by Ammer et al. (2006), earthworm populations are largely determined by primary factors such as soil properties and altitude. 
Table 4

Mean biomasses $\left(\mathrm{g} \mathrm{m}^{-2}\right)$ and abundances (ind $\mathrm{m}^{-2}$ ) of earthworm species considered as not infrequent, according to altitudinal level and forest stages Number in brackets are standard deviations (SD).

\begin{tabular}{|c|c|c|c|c|c|c|c|c|c|}
\hline & \multicolumn{9}{|c|}{ Biomass $\left(\mathrm{g} \mathrm{m}^{-2}\right)$} \\
\hline & \multicolumn{3}{|l|}{ Subalpine } & \multicolumn{3}{|l|}{ Mountain } & \multicolumn{3}{|l|}{ Hill } \\
\hline & PP & I & $\mathrm{M}$ & PP & I & $\mathrm{M}$ & PP & I & $\mathrm{M}$ \\
\hline Dendrobaena octaedra & $0.37(0.46)$ & $0.16(0.10)$ & $0.19(0.19)$ & $0.80(1.27)$ & $0.47(0.22)$ & $0.04(0.07)$ & $1.86(1.07)$ & $0.58(0.98)$ & $0.78(1.20)$ \\
\hline Dendrodrilus rubidus & $0.60(0.53)$ & $0.08(0.10)$ & $0.15(0.24)$ & $0.00(0.01)$ & 0 & $0.01(0.02)$ & $0.14(0.16)$ & $0.04(0.06)$ & 0 \\
\hline Lumbricus meliboeus & $4.16(3.67)$ & $2.26(3.07)$ & $0.48(0.60)$ & 0 & 0 & 0 & 0 & 0 & 0 \\
\hline Lumbricus rubellus & $3.99(4.75)$ & $2.92(4.77)$ & $6.92(8.56)$ & $3.56(2.04)$ & $1.29(0.95)$ & $0.85(1.43)$ & $10.75(13.39)$ & $3.12(4.55)$ & $0.78(0.96)$ \\
\hline Aporrectodea caliginosa nocturna & 0 & 0 & 0 & $0.04(0.10)$ & $0.41(0.39)$ & $13.95(12.27)$ & $35.01(23.36)$ & $58.80(26.90)$ & $52.21(34.64)$ \\
\hline Lumbricus terrestris & 0 & 0 & 0 & $9.57(10.21)$ & $2.77(2.82)$ & $12.10(6.20)$ & $3.51(5.14)$ & $5.04(5.96)$ & $15.61(20.56)$ \\
\hline Allolobophora chlorotica chlorotica & 0 & 0 & 0 & $0.02(0.03)$ & $0.41(0.71)$ & $0(0.01)$ & $2.81(6.65)$ & 0 & 0 \\
\hline Aporrectodea caliginosa caliginosa & $2.51(2.64)$ & $0.03(0.04)$ & 0 & $0.83(1.12)$ & $0.21(0.22)$ & $1.32(2.26)$ & $6.47(6.53)$ & $2.74(2.90)$ & $0.65(0.69)$ \\
\hline Aporrectodea handlirschi handlirschi & $0.02(0.03)$ & $0.16(0.39)$ & $3.06(1.29)$ & 0 & 0 & 0 & $0.06(0.14)$ & 0 & 0 \\
\hline Aporrectodea icterica icterica & 0 & 0 & 0 & 0 & 0 & $3.88(3.39)$ & 0 & $1.37(1.72)$ & $3.20(5.28)$ \\
\hline Aporrectodea rosea rosea & 0 & $0.00(0.01)$ & $2.11(3.84)$ & $0.17(0.33)$ & $3.50(3.92)$ & $5.33(2.86)$ & $1.81(2.81)$ & $4.20(4.36)$ & $2.82(3.07)$ \\
\hline Octolasion cyaneum & 0 & 0 & $1.83(3.07)$ & 0 & 0 & $2.83(5.65)$ & 0 & 0 & 0 \\
\hline \multirow[t]{4}{*}{ Octolasion tyrtaeum } & $13.77(5.94)$ & $3.84(6.42)$ & $5.57(6.74)$ & $2.46(1.98)$ & $11.45(4.33)$ & $4.67(4.19)$ & $4.74(3.62)$ & $1.38(3.32)$ & $2.22(4.74)$ \\
\hline & \multicolumn{9}{|c|}{ Abundance (ind. $\mathrm{m}^{-2}$ ) } \\
\hline & \multicolumn{3}{|l|}{ Subalpine } & \multicolumn{3}{|l|}{ Mountain } & \multicolumn{3}{|l|}{ Hill } \\
\hline & $\mathrm{PP}$ & $\mathrm{I}$ & $\mathrm{M}$ & $\mathrm{PP}$ & $\mathrm{I}$ & $\mathrm{M}$ & $\mathrm{PP}$ & $\mathrm{I}$ & $\mathrm{M}$ \\
\hline Dendrobaena octaedra & $3.56(3.73)$ & $2.28(1.68)$ & $3.08(3.41)$ & $17.23(24.45)$ & $8.94(4.72)$ & $0.46(0.92)$ & $27.92(15.62)$ & $11.92(19.37)$ & $14.22(19.21)$ \\
\hline Dendrodrilus rubidus & $9.78(9.17)$ & $1.11(1.81)$ & $2.19(3.65)$ & $0.10(0.15)$ & 0 & $0.08(0.17)$ & $3.81(4.37)$ & $1.22(2.08)$ & 0 \\
\hline Lumbricus meliboeus & $16.17(12.35)$ & $6.67(7.94)$ & $1.31(1.24)$ & 0 & 0 & 0 & 0 & 0 & 0 \\
\hline Lumbricus rubellus & $16.56(19.06)$ & $7.92(12.29)$ & $24.42(35.53)$ & $7.80(4.95)$ & $2.78(1.75)$ & $2.17(3.70)$ & $40.86(51.23)$ & $9.22(11.92)$ & $2.33(2.98)$ \\
\hline Aporrectodea caliginosa nocturna & 0 & 0 & 0 & $0.03(0.07)$ & $0.56(0.69)$ & $21.50(23.89)$ & $78.78(60.93)$ & $106.9(58.01)$ & $75.42(51.85)$ \\
\hline Lumbricus terrestris & 0 & 0 & 0 & $6.33(5.98)$ & $1.50(1.80)$ & $11.63(6.10)$ & $3.83(5.14)$ & $7.86(9.55)$ & $16.58(22.02)$ \\
\hline Allolobophora chlorotica chlorotica & 0 & 0 & 0 & $0.07(0.09)$ & $3.33(5.77)$ & $0.04(0.08)$ & $27.19(64.51)$ & 0 & 0 \\
\hline Aporrectodea caliginosa caliginosa & $17.06(22.62)$ & $0.06(0.09)$ & 0 & $4.50(5.76)$ & $0.83(0.73)$ & $4.92(8.52)$ & $57.31(59.13)$ & $35.19(40.06)$ & $6.39(7.60)$ \\
\hline Aporrectodea handlirschi handlirschi & $0.17(0.29)$ & $0.78(1.82)$ & $22.89(9.39)$ & 0 & 0 & 0 & $0.69(1.70)$ & 0 & 0 \\
\hline Aporrectodea icterica icterica & 0 & 0 & 0 & 0 & 0 & $11.21(11.20)$ & 0 & $6.64(7.72)$ & $7.72(13.15)$ \\
\hline Aporrectodea rosea rosea & 0 & $0.03(0.07)$ & $12.89(21.52)$ & $0.90(1.92)$ & $19.72(20.63)$ & $35.17(21.28)$ & $14.83(26.86)$ & $50.97(60.70)$ & $22.78(29.24)$ \\
\hline Octolasion cyaneum & 0 & 0 & $2.50(3.28)$ & 0 & 0 & $2.17(4.33)$ & 0 & 0 & 0 \\
\hline Octolasion tyrtaeum & $66.06(10.91)$ & $8.61(13.52)$ & $16.22(18.90)$ & $14.10(10.06)$ & $67.28(44.38)$ & $19.29(20.20)$ & $29.56(28.70)$ & $13.39(32.39)$ & 8.78 (17.73) \\
\hline
\end{tabular}

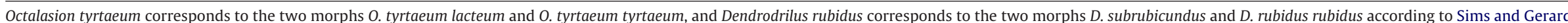
(1999). Aporectodea caliginosa nocturna and Aporectodea caliginosa caliginosa were kept separately because of their different ecological behaviour (Sims and Gerard 1999). 

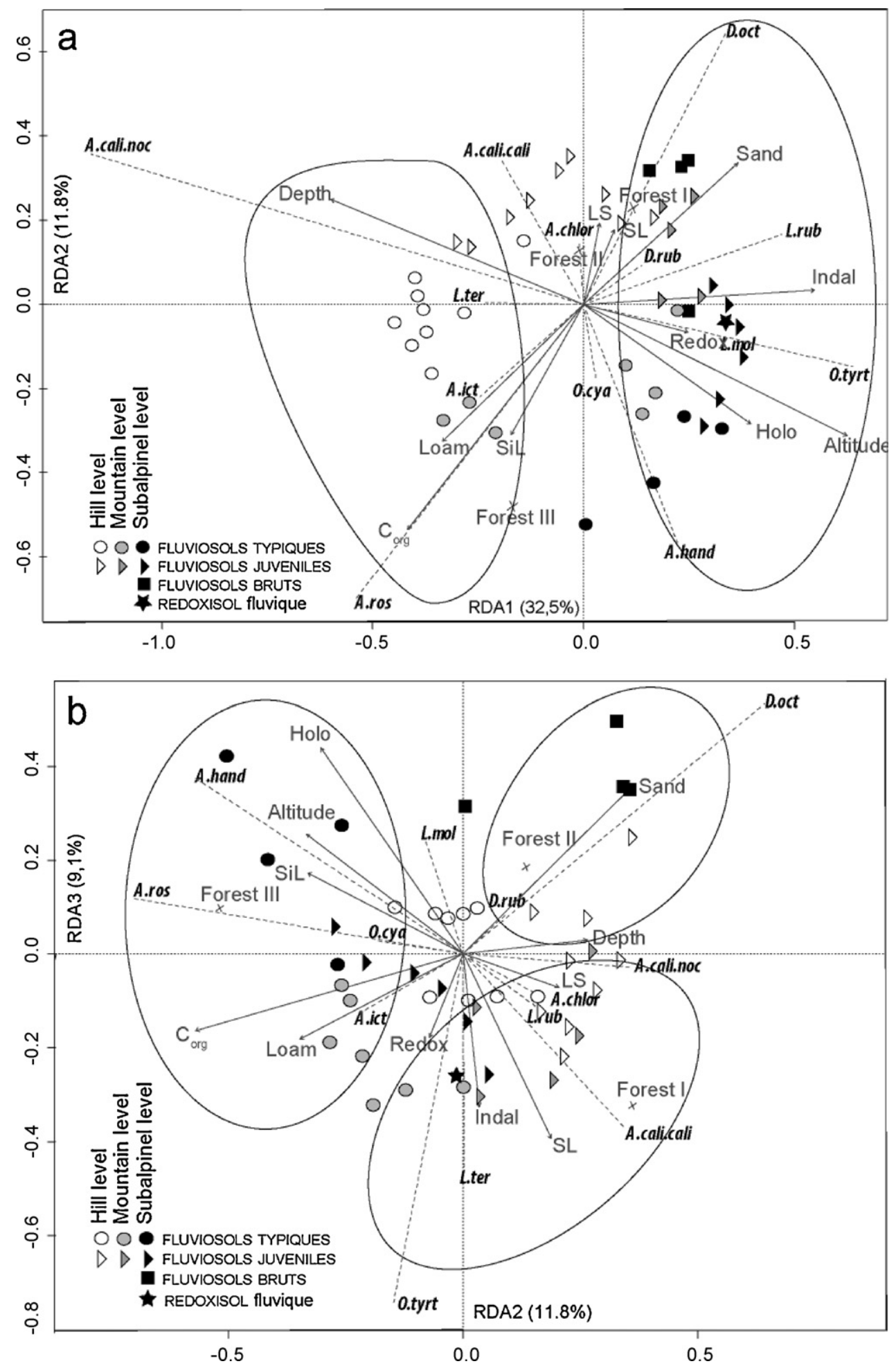

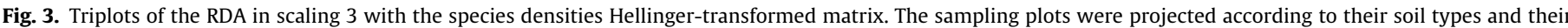

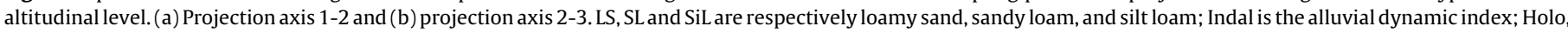

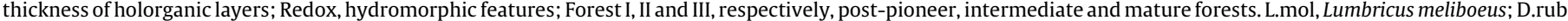

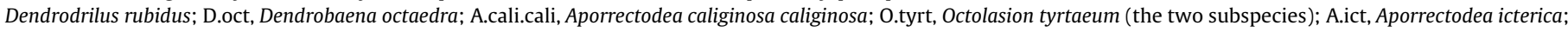

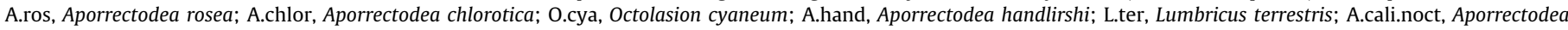
caliginosa nocturna.

\section{Soil characteristics and earthworm communities}

Soil depth is one of the most important factors explaining the distribution of earthworm communities especially for anecic species (Bouché 1972; Phillipson et al. 1976; Guenat et al. 1999).
In alluvial forests, the soil depth is mainly determined by fluvial dynamics (alluvial index and altitude) leading to erosion and sedimentation processes. In fact, Burrin and Jones (1991) found thickening the alluvial deposits from the river source to its mouth due to an increase in sedimentation and a decrease in erosion processes. 
Moreover, in a mature vegetation stage, Amoros and Wade (1996) observed a rise in the soil surface compared to the river bed. This soil depth variation explains why anecic species (in particular $A$. cali. nocturna and $L$. terrestris) were found both at hill and mountain levels, with $L$. terrestris only observed in soils under mature forests.

Other factors, such as soil texture and organic matter content, influence the distribution of earthworm communities. However, distinguishing the effect of fine texture from $C_{\text {org }}$ content is difficult because of the strong relationship between these two parameters, particularly in old alluvial terraces (Guenat et al. 2003). Soil texture had a major effect on epigeics, which were more associated with coarse sandy texture while anecics (especially A. cali. nocturna) preferred mature stages with the finest texture (Bullinger-Weber et al. 2007). Some of our soils had a sandy texture. This abrasive material, associated with low organic matter content alongside low water retention, is known to be unfavourable to earthworm colonisation (Lee 1985). As a consequence, these soils under different forest stages were dominated by epigeic species, such as $D$. octaedra and to a lesser extent $D$. rubidus that strictly feed on surface litter. Homogeneous loamy to silty loamy textures with high $\mathrm{C}_{\text {org }}$ stocks were mostly found in mature forest stages and are frequent were the three sites. At the subalpine level, these conditions favoured the settlement of endogeic species as A. rosea and A. handlirshi, and to a lesser extent, $O$. cyaneum. At the mountain and hill levels, the same species plus $A$. icterica were present in these FLuviosols TYPIQUES. Nordström and Rundgren (1974) already reported a correlation between $C_{\text {org }}$ and the presence of $A$. rosea, but our results suggested that this relationship is also of relevance for the above mentioned endogeic species. Thus, in alluvial forests these endogeic species could be indicators of soil stabilisation (i.e. maturation).

On the contrary, FLuviosols JUVENILEs that are frequently subjected to alluvial dynamics (flooding events and alluvium depositions), were inhabited by species such as L. moliboeus, L. rubellus, D. octaedra, A. cali. caliginosa and O. tyrtaeum. All these species have been recorded as inhabitants of frequently flooded soils (Ausden et al. 2001; Beylich and Graefe 2002; Plum and Filser 2005; Zorn et al. 2005; Ivask et al. 2007) or as the first earthworm colonisers (Eijsackers et al. 2009).

Beside soil depth, organic matter and texture, strong hydromorphic conditions were occasionally observed. At the subalpine level, species such as O. tyrtaeum (especially O. t. tyrtaeum), L. moliboeus, L. rubellus and D. rubidus were dominant proving their ability to tolerate such pedological conditions even in the upper soil horizons. However, these hydromorphic features were only observed in some alluvial soils that are also subjected to slope water flows. At the hill level, hydromorphic features were also present in one soil in which $A$. chlorotica (including green morph) and A. cali. caliginosa were numerous. Some of these species found in these particular soils are known to resist to water saturation as shown by Zorn et al. (2008). However, supplementary data acquisition in hydromorphic soils is necessary to support those statements.

\section{Conclusion}

Along altitudinal and forest succession gradients in alluvial soils, earthworm communities are mainly dependent on soil parameters, then on altitude and finally, and to a lesser extent, on forest successional stage. Soil parameters highly overlap with the two gradients studied (altitude and forest stage). The complexity of the floodplain system and the mosaic of habitats created by fluvial dynamics lead to a high diversity of earthworms in terms of species composition, biomass and abundance in such confined areas. We demonstrated that changes in earthworm communities tend to reflect a gradient in alluvial dynamics. This conclusion reinforces the potential role of earthworms as bioindicators in natural and/or semi natural alluvial ecosystems at different altitudes.

\section{Acknowledgments}

The authors gratefully thank Dr. Roxane Kohler-Milleret and Dr. Florian Kohler for their statistical advice and Ms. Marie Sudki for English language revision of the manuscript. This research was supported by grant $n^{\circ} 3100 A 0-116825$ (FLOOD STRUBIO project) from the Swiss National Science Foundation.

\section{References}

Ammer, S., Weber, K., Abs, C., Ammer, C., Prietzel, J., 2006. Factors influencing the distribution and abundance of earthworm communities in pure and converted Scots pine stands. Appl. Soil Ecol. 33, 10-21.

Amoros, C., Wade, P.M., 1996. Ecological successions. In: Petts, G., Amoros, C. (Eds.), Fluvial Hydrosystems. Chapman \& Hall, London, pp. 211-241.

Ausden, M., Sutherland, W.J., James, R., 2001. The effects of flooding lowland wet grassland on soil macroinvertebrate prey of breeding wading birds. J. Appl. Ecol. 38, 320-338.

Baize, D., Girard, M.-C., 2009. Référentiel Pédologique. Quae, Versailles.

Beylich, A., Graefe, U., 2002. Annelid coenoses of wetlands representing different decomposer communities. In: Broll, G., Merbach, W., Pfeiffer, E.-M. (Eds.), Wetlands in Central Europe. Soil Organisms, Soil Ecological Processes and Trace Gas Emissions. Springer, Berlin, pp. 1-10.

Blakemore, R.J., 2007. An updated list of valid, invalid and synonym names of Criodrioidea (Criodrilidae) and Lumbricoidea (Annelida: Oligochaeta: Sparganophilidae, Ailoscolecidae, Hormogastridae, Lumbricidae, and Lutodrilidae). http://bio-eco.eis.ynu.ac.jp/eng/database/earthworm/Lumbricidae.pdf.

Bouché, M.B., 1972. Lombriciens de France, Ecologie et Systématique. I.N.R.A. Publ., Paris.

Bouché, M.B., 1977. Stratégies lombriciennes. Ecol. Bull. 25, 122-132.

Bullinger-Weber, G., Le Bayon, R.C., Guenat, C., Gobat, J.M., 2007. Influence of some physicochemical and biological parameters on soil structure formation in alluvial soils. Eur. J. Soil Biol. 43, 57-70.

Burrin, P.J., Jones, D.K.C., 1991. Environmental processes and fluvial responses in a small temperate zone catchment: a case study of the Sussex Ouse Valley, Southeast England. In: Starkel, L., Gregory, K.J., Thornes, J.B. (Eds.), Temperate Palaeohydrology. John Wiley, Chichester.

Carter, M.R., Gregorich, E.G., 2007. Soil Sampling and Methods of Analysis. CRC Press.

Cuendet, G., 1986. Le peuplement lombricien d'une pelouse alpine à Bossetan (frontière franco-suisse, Valais) et répartition des lombriciens en altitude. Bull. Soc. Vaud. Sci. Nat. 78, 133-144

Cuendet, G., 1997. Peuplements lombriciens des prairies permanentes du plateau Suisse. Cah. Environ. 291. OFEFP, Berne.

Decaëns, T., 2010. Macroecological patterns in soil communities. Global Ecol. Biogeogr. 19, 287-302.

Edwards, C.A., 2004. Earthworm Ecology, 2nd ed. CRC Press LLC, St. Lucie Press, Boca Raton.

Edwards, C.A., Bohlen, P.J., 1996. The Biology and Ecology of Earthworms. Chapman and Hall London.

Eijsackers, H., 2010. Earthworms as colonisers: primary colonisation of contaminated land, and sediment and soil waste deposits. Sci. Total Environ. 408, 1759-1769.

Eijsackers, H., Bruggeman, J., Harmsen, J., De Kort, T., Schakel, A., 2009. Colonization of PAH-contaminated dredged sediment by earthworms. Appl. Soil Ecol. 43, 216-225.

Gallandat, J.-D., Gobat, J.-M., Roulier, C., 1993. Cartographie des Zones Alluviales d'Importance Nationale. Cah. Environ. 199. OFEFP, Berne, p. 112.

Guenat, C., Bureau, F., Charnet, F., 2003. Genèse, diversité et fonctionnement des sols sous la dépendance d'un cours d'eau. In: Piégay, H., Pautou, G., Ruffinoni, C. (Eds.), Les Forêts Riveraines des Cours d'Eau. Ecologie, Fonctions et Gestion. Institut pour le Développement Forestier, Paris, pp. 46-71.

Guenat, C., Bureau, F., Weber, G., Toutain, F., 1999. Initial stages of soil formation in a riparian zone: importance of biological agents and lithogenic inheritance in the development of the soil structure. Eur. J. Soil Biol. 35, 153-161.

IUSS Working Group WRB, 2006. World Reference Base for Soil Resources, 2nd ed. World Soil Resources Report 103, FAO, Rome.

Ivask, M., Truu, J., Kuu, A., Truu, M., Leito, A., 2007. Earthworm communities of flooded grasslands in Matsalu, Estonia. Eur. J. Soil Biol. 43, 71-76.

Jones, C.G., Lawton, J.H., Shachak, M., 1997. Ecosystem engineering by organisms: why semantics matters. Trends Ecol. Evol. 12, 275.

Korte, T., Baki, A.B.M., Ofenbock, T., Moog, O., Sharma, S., Hering, D., 2010. Assessing river ecological quality using benthic macroinvertebrates in the Hindu KushHimalayan region. Hydrobiologia 651, 59-76.

Kuhn, N., Amiet, R., 1988. Inventaire des Zones Alluviales d'Importance Nationale. Part. Gén., Dép. Féd. Int. OFEFP, Berne, p. 41.

Lapied, E., Nahmani, J., Rousseau, G.X., 2009. Influence of texture and amendments on soil properties and earthworm communities. Appl. Soil Ecol. 43, 241249 . 
G Model

PEDOBI-50298; No. of Pages 10

10

C. Salomé et al. / Pedobiologia $x x x$ (2011) $x x x-x x x$

Lavelle, P., 1988. Earthworm activities and the soil system. Biol. Fert. Soils 6, 237251.

Lavelle, P., Bignell, D., Lepage, M., Wolters, V., Roger, P., Ineson, P., Heal, O.W., Dhillion, S., 1997. Soil function in a changing world: the role of invertebrate ecosystem engineers. Eur. J. Soil Biol. 33, 159-193.

Lawrence, A.P., Bowers, M.A., 2002. A test of the 'hot' mustard extraction method of sampling earthworms. Soil Biol. Biochem. 34, 549-552.

Lee, K.E., 1985. Earthworms: Their Ecology and Relationships with Soil and Land Use. Academic Press, Australia.

Legendre, P., Gallagher, E.D., 2001. Ecologically meaningful transformations for ordination of species data. Oecologia 129, 271-280.

Mather, J.G., Christensen, O., 1988. Surface movements of earthworms in agricultural land. Pedobiology 32, 399-405.

McGinness, H.M., Arthur, A.D., Reid, J.R.W., 2010. Woodland bird declines in the Murray-Darling Basin: are there links with floodplain change? Range. J. 32 315-327.

Nordström, S., Rundgren, S., 1974. Environmental factors and lumbricid associations in southern Sweden. Pedobiology 14, 1-27.

Pets, G.E., Amoros, C., 1996. Fluvial Hydrosystems. Chapman \& Hall, London.

Phillipson, J., Abel, R., Steel, J., Woodell, S.R.J., 1976. Earthworms and factors governing their distribution in an English beechwood. Pedobiology 16, $258-285$.

Pizl, V., 1999. Earthworm communities in hardwood floodplain forests of the Morava and Dyje rivers as influenced by different inundation regimes. Ekol. Bratislava $18,197-204$.

Plum, N., 2005. Terrestrial invertebrates in flooded grassland: a literature review. Wetlands 25, 721-737.
Plum, N.M., Filser, J., 2005. Floods and drought: response of earthworms and potworms (Oligochaeta: Lumbricidae, Enchytraeidae) to hydrological extremes in wet grassland. Pedobiology 49, 443-453.

R Development Coreteam, 2008. R: A Language and Environment for Statistical Computing. R Foundation for Statistical Computing.

Schnitzler-Lenoble, A., 2007. Forêts Alluviales d'Europe. Edition Lavoisier, Cachan.

Schütz, K., Nagel, P., Dill, A., Scheu, S., 2008. Structure and functioning of earthworm communities in woodland flooding systems used for drinking water production. Apple. Soil Ecol. 39, 342-351.

Sims, G.K., Gerard, B.M., 1999. Earthworms. Linnean Society of London, London.

Tockner, K., Klaus, I., Baumgartner, C., Ward, J.V., 2006. Amphibian diversity and nestedness in a dynamic floodplain river (Tagliamento, NE-Italy). Hydrobiologia $565,121-133$.

Ward, J.V., Tockner, K., Arscott, D.B., Claret, C., 2002. Riverine landscape diversity. Freshwater Biol. 47, 517-539.

Williams, A.K., Ratnaswamy, M.J., Renken, R.B., 2001. Impacts of a flood on small mammal populations of lower Missouri River floodplain forests. Am. MidI. Nat. $146,217-221$

Wright, J.P., Gurney, W.S.C., Jones, C.G., 2004. Patch dynamics in a landscape modified by ecosystem engineers. Oiks 105, 336-348.

Zorn, M.I., Van Gestel, C.A.M., Eijsackers, H., 2005. Species-specific earthworm population responses in relation to flooding dynamics in a Dutch floodplain soil. Pedobiology 49, 189-198.

Zorn, M.I., Van Gestel, C.A.M., Morrien, E., Wagenaar, M., Eijsackers, H., 2008. Flooding responses of three earthworm species, Allolobophora chlorotica, Aporrectodea caliginosa and Lumbricus rubellus, in a laboratory-controlled environment. Soil Biol. Biochem. 40, 587-593.

Please cite this article in press as: Salomé, C., et al., Earthworm communities in alluvial forests: Influence of altitude, vegetation stages and soil parameters. Pedobiologia - Int. J. Soil Biol. (2011), doi:10.1016/j.pedobi.2011.09.012 